\title{
HUBUNGAN SELF CARE ACTIVITY DENGAN TINGKAT DEPRESI PADA PASIEN CONGESTIVE HEART FAILURE DI POLIKLINIK JANTUNG RSU FAMILI HUSADA
}

\author{
Luh Desy Suandari' ${ }^{1}$ Putu Wira Kusuma Putra ${ }^{2}$, A. A. Kompiang Ngurah Darmawan ${ }^{3}$ \\ ${ }_{1,2,3}$ Program Studi S-1Keperawatan, STIKes Bina Usada Bali \\ Email: 1desysuandari21@gmail.com, 2putuwirakusuma@gmail.com, ${ }^{3}$ agungdarmawan32@yahoo.com
}

\begin{abstract}
ABSTRAK
Gejala jangka panjang yang timbul pada pasien CHF akan memengaruhi status fungsional dan distress psikologis, contohnya depresi yang berpengaruh terhadap kualitas hidup pasien. Self care activity mampu merubah gaya hidup dan meningkatkan kualitas hidup pasien. Penelitian ini bertujuan untuk mengetahui hubungan self care activity dengan tingkat depresi pada pasien CHF. Jenis penelitian ini adalah kuantitatif dengan desain deskriptif korelasional dengan pendekatan cross sectional. Total responden yang berpartisipasi adalah 50 responden dan dipilih menggunakan teknik purposive sampling. Kuesioner yang digunakan yaitu self care of heart failure index (SCHFI), dan the hospital anxiety dan depression scale (HADS). Hasil penelitian menunjukkan dari 50 responden sebagian besar memiliki tingkat depresi sedang yaitu 30 responden (60\%). Sedangkan self care activity sebagian besar memiliki self care activity yang cukup yaitu 36 responden (72\%). Hasil uji rank spearman test menunjukan nilai $p$-value 0,000 $\alpha=0,05$ yang artinya ada hubungan self care activity dengan tingkat depresi pada pasien CHF di poliklinik Jantung RSU Famili Husada.
\end{abstract}

kata Kunci : Congestive Heart Failure, Self Care Activity, Tingkat Depresi.

\section{ABSTRACT}

Long-term symptoms that arise in CHF patients will affect the functional status and psychological distress, for example, depression which affects the patient's quality of life. Self-care activities can change the lifestyle and improve the quality of life of patients. This study aims to determine the relationship between self care activity and depression levels in patients with CHF. This type of research is quantitative with a descriptive correlational design with a cross sectional approach. The total number of respondents who participated were 50 respondents and were selected using a purposive sampling technique. The instruments used were the self care of heart failure index (SCHFI) questionnaire and the hospital anxiety and depression scale (HADS) questionnaire. The results showed that most of the 50 respondents had a moderate level of depression, namely 30 respondents (60\%). Meanwhile, most of the self-care activities had sufficient self-care activities, namely 36 respondents (72\%). The result of the rank spearman test shows a p-value of $0.000 \alpha=0.05$, which means that there is a relationship between selfcare activity and depression levels in CHF patients at cardiac clinic the Famili Husada Hospital.

Keywords : Congestive Heart Failure, Self-Care Activity, Depression Level.

\section{PENDAHULUAN}

Congestive heart failure merupakan suatu keadaan dimana jantung tidak mampu memompa darah yang adekuat untuk memenuhi kebutuhan oksigen dan nutrisi ke jaringan (Smeltzer and Bare, 2017). Meskipun terapi dan pencegahan telah mengalami kemajuan yang pesat, tetapi angka mortalitas dan morbiditas tetap tinggi sehingga dapat memengaruhi kualitas hidup pasien. Dapat dilihat dari data WHO tahun 2015 menunjukkan bahwa 70\% kematian di dunia disebabkan penyakit jantung yaitu 17.7 juta dari 39,5 juta kematian, dan meningkat sebanyak 17,9 juta orang dari 56,5 juta kematian.

Gejala gagal jantung ditandai dengan kerusakan struktur dan fungsi jantung secara tidak langsung mempengaruhi kualitas hidup pasien, seperti sesak nafas dan kelelahan. Tingginya angka rehospitalisasi dan mortalitas dapat menyebabkan timbulnya keterbatasan fungsional dan distress psikologis bagi pasien, seperti keterbatasan fisik, sosial, fungsi peran dan fungsi mental sebagai dampak dari penyakit congestive heart failure sedangkan distress psikologis dikaitkan dengan perasaan cemas, depresi, disforia, dan bentuk reaksi psikis. 
WHO menyatakan bahwa depresi menempati urutan keempat penyakit didunia yang dikaitkan dengan keterbatasan fungsi fisik dan sosial sebagai dampak dari menderita penyakit kronik. Prevalensi kumulatif heart failure berdasarkan (Praptiwi, 2017) hasil analisis 27 penelitian menunjukkan angka yang berkisar antara $9 \%$ sampai dengan 60\%. Dalam penelitian (Kaawoan, 2012) menyatakan bahwa ratarata prevalensi depresi meningkat $11 \%$ sampai $25 \%$ pada pasien rawat jalan dan $35 \%$ sampai $70 \%$ pada pasien rawat inap.

\section{Data AHA (American Health} Assosiation) di Amerika tahun 2017 angka insiden penderita gagal jantung sebanyak 6,5 juta orang (Benjamin et al., 2017). Riskesdas tahun 2013 menyatakan bahwa prevalensi dari penderita gagal jantung yang terdiagnosis oleh dokter di Indonesia yaitu sebanyak 0,13\% (Riskesdas, 2013) dan di tahun 2018 mengalami peningkatan sebanyak 1,5\% (Riskesdas, 2018). Data tahun 20172019 di Provinsi Bali menyatakan bahwa jumlah pasien gagal jantung kongestif termasuk dalam 10 besar penyakit rawat jalan di provinsi bali yaitu di tahun 2017 sebanyak 1.370 pasien, tahun 2018 sebanyak 1.400 pasien dan di tahun 2019 sebanyak 1.650 pasien (Dinas Kesehatan Provinsi Bali, 2018). Hal ini sejalan dengan data rekam medis dari tahun 2017-2019 jumlah pasien gagal jantung kongestif yang rawat jalan di RSU Famili Husada kabupaten Gianyar pada tahun 2017 sebanyak 540 pasien, 2018 sebanyak 759 pasien, 2019 sebanyak 915 orang.

Kondisi depresi pada pasien congestive heart ailure sering dikaitkan dengan faktor psikososial seperti stress yang disebabkan oleh situasi kehidupan, kepatuhan terhadap pengobatan, tidak melakukan diet dan jarang melakukan aktivitas fisik. Apabila hal ini tidak dipatuhi, akan berpengaruh terhadap kualitas hidup pasien. Menurut (McGowan, 2014) depresi dapat menurunkan kualitas hidup pasien serta secara signifikan meningkatkan risiko kematian pasien dengan congestive heart failure. Kompleksitas faktor risiko heart failure menyebabkan perubahan patofisiologi terjadinya kerusakan kontraktilitas ventrikel, peningkatan after load dan gangguan pengisian diastolik yang dapat menurunkan cardiac output (Lilly,
2013). Ketika cardiac output tidak mampu memenuhi kebutuhan tubuh maka jantung akan melakukan mekanisme kompensasi untuk meningkatkan cardiac output dan tekanan darah. Misalnya terdapat bengkak pada tungkai kaki dan ortopnoe yang timbul akibat abnormalitas keseimbangan cairan akibat disfungsi jantung. Diperkirakan sekitar 90\% gejala utama yang paling sering dilaporkan oleh pasien heartfailure yaitu sesak nafas dan kelelahan (Tatukude, Rampengan and Panda, 2016).

Perubahan struktur dan fungsi jantung akan berdampak secara langsung pada status fungsional, hal ini juga mempengaruhi kemampuan pasien untuk melakukan self care activity. Ketidakmampuan pasien untuk beradaptasi terhadap penyakitnya seperti sesak nafas, intoleransi aktivitas dan kelelahan dapat mempengaruhi aktivitas pasien. Sebagian pasien menyatakan bahwa mereka belum melaksanakan perawatan diri seperti menajemen pengobatan, melakukan diet, berolahraga, mengurangi cairan, dan menimbang berat badan. Ketidakmampuan melaksanakan self care dengan baik, sehingga gejala yang dirasakan semakin berat dan menyebabkan pasien menjalani hospitalisasi berulang. Dengan meningkatkan kemampuan self care activity dapat mengendalikan terjadinya perburukan kondisi serta menghindari re-hospitalisasi bagi pasien (Britz and Dunn, 2010).

Self care activity adalah proses pengambilan keputusan secara aktif yaitu merubah pola hidup untuk mempertahankan stabilitas fisiologis (maintenace), mampu mengetahui tanda dan gejala yang dialami (management) serta keyakinan pasien untuk sembuh (confidence). Self care penting bagi pasien congestive heart failure. Kemampuan self care diperoleh melalui pengalaman pasien menderita penyakit kronis sehingga berdampak pada perubahan pola hidup dan secara langsung mempengaruhi kualitas hidup pasien (Smeltzer and Bare, 2017).

Menurut (Britz and Dunn, 2010) dalam studinya mengenai kemampuan self care pasien congestive heart failure yang dihubungkan dengan perubahan kualitas hidup, menunjukkan bahwa hanya self care confidence dan persepsi yang baik terhadap kesehatan yang mempunyai hubungan dengan peningkatan kualitas hidup. Peran 
perawat klinik dapat meningkatkan kemampuan hidup pasien dengan congestive heart failure serta mempertahankan perilaku self care yang baik, hal ini mampu menurunkan angka kejadian re-hospitalisasi serta jumlah hari rawat (Prihatiningsih and Sudyasih, 2018). Menurut penelitian (Kaawoan, 2012) menyatakan bahwa program self care management dapat menurunkan jumlah kejadian hospitalisasi dan re-hospitalisasi bagi pasien heart failure, serta berpengaruh terhadap kualitas hidup pasien heart failure.

Hasil wawancara yang dilakukan pada tanggal 1 April 2020 pada 5 orang pasien CHF yang sedang kontrol rawat jalan di Poli Jantung ditemukan hanya 1 responden $(20 \%)$ yang sudah rutin melakukan self care management secara mandiri, 4 responden (80\%) pasien mengatakan masih sulit mengontrol pola makan dan motivasi untuk berolahraga kurang. Berdasarkan permasalahan diatas peneliti tertarik untuk mengetahui adakah "Hubungan Self Care Activity dengan Tingkat Depresi Pada Pasien CHF di Poliklinik Jantung RSU Famili Husada".

\section{METODE}

Desain penelitian ini adalah deskriptif korelasional dengan pendekatan cross sectional. Responden pada penelitian ini adalah seluruh pasien CHF yang kontrol di Poliklinik Jantung RSU Famili Husada. Sampel dipilih dengan tehnik purposive sampling. Populasi pasien CHF sebanyak 100 pasien, besar sampel yang diperoleh dengan rumus solvin sebanyak 50 responden yang memenuhi kriteria inklusi dan eksklusi yaitu:

1. kriteria inklusi

a. Pasien yang didiagnosa congestive heart failure sesuai dengan catatan rekam medis serta pernah opname dengan $\mathrm{CHF}$

b. Bisa berkomunikasi dengan peneliti dengan bahasa tulis atau lisan.

2. Kriteria eksklusi,

a. Pasien CHF dengan gangguan neurologis (gangguan fungsi kognitif), penyakit stroke dan renal disease yang menjalani hemodialisa.

Responden yang bersedia dan memenuhi kriteria diberikan infom concent menjadi responden. Instrumen untuk mengukur self care activity menggunakan Kuesioner SCHFI (Self care of heart failure index) dan Tingkat Depresi menggunakan Kuesioner HADS (The Hospital Anxiety dan depression scale). Kuesioner ini telah dilakukan uji validitas dan reliabilitas, hasil uji pada kuesioner self care dengan nilai Cronbach alpha $=0,956$ dan kuesioner tingkat depresi nilai Cronbach alpha $=0,954$ (Kaawoan, 2012).

Hasil pengambilan data dilakukan pengolahan coding, editing, cleaning, dan tabulating kemudian analisis data menggunakan uji rank sperman test karena data menggunakan skala pengukuran ordinal. Pada penelitian ini hipotesis diterima apabila $\mathrm{p}$ value $<0,05$ dan tingkat kepercayaan $95 \%$. Penelitian ini telah dinyatakan lulus uji laik etik oleh Komisi Etik Penelitian Kesehatan Stikes Bina Usada Bali dibuktikan oleh surat keterangan lolos kaji etik No. 193/EA/KEPKBUB-2020.

\section{HASIL DAN PEMBAHASAN}

3.1 Hasil Penelitian

Anasis Univariat

a. Karakteristik Responden

Tabel 1. Distribusi Frekuensi Karakteristik responden CHF di Poliklinik Jantung RSU Famili Husada

\begin{tabular}{lcc}
\hline Umur & $\begin{array}{c}\text { Frekuensi } \\
(\boldsymbol{f})\end{array}$ & $\begin{array}{c}\text { Persentase } \\
(\boldsymbol{\%})\end{array}$ \\
\hline $\begin{array}{l}\text { Lansia awal } \\
(46-55 \text { tahun })\end{array}$ & 15 & 30 \\
\hline $\begin{array}{l}\text { Lansia akhir } \\
(56-65 \text { tahun })\end{array}$ & 25 & 50 \\
\hline$>65$ tahun & 10 & 20 \\
\hline Jumlah & 50 & 100 \\
\hline Jenis Kelamin & Frekuensi & Persentase \\
& $(\boldsymbol{f})$ & $(\%)$ \\
\hline Laki- laki & 30 & 60 \\
\hline Perempuan & 20 & 40 \\
\hline Jumlah & 50 & 100 \\
\hline Tingkat & Frekuensi & Persentase \\
Pendidikan & $(\boldsymbol{f})$ & $(\boldsymbol{\%})$ \\
\hline SD & 10 & 20 \\
\hline SMP & 10 & 20 \\
\hline SMA & 25 & 50 \\
\hline PT & 5 & 10 \\
\hline Jumlah & 50 & 100 \\
\hline Pekerjaan & Frekuensi & Persentase \\
& $(\boldsymbol{f})$ & $(\boldsymbol{\%})$ \\
\hline Wiraswata & 25 & 50 \\
\hline Swasta & 15 & 30 \\
\hline Tidak bekerja & 10 & 20 \\
\hline Jumlah & 50 & 100 \\
\hline & & \\
\hline & & \\
\hline
\end{tabular}


Sumber: Data Lampiran 10

Berdasarkan tabel 1, menunjukan bahwa dari 50 responden sebagian besar adalah berusia 56-65 tahun yaitu 25 responden $(50 \%)$, dengan jenis kelamin laki-laki yaitu 30 responden $(60 \%)$, tingkat pendidikan SMA yaitu 25 responden $(50 \%)$ serta pekerjaan wiraswasta sebanyak 25 responden $(50 \%)$.

\section{b. Self Care Activity}

Tabel 2. Distribusi Data Self Care Activity Self Care Activity Frekuensi Persentase

\begin{tabular}{ccc} 
& $(\boldsymbol{f})$ & $(\boldsymbol{\%})$ \\
\hline Kurang & 2 & 4 \\
\hline Cukup & 36 & 72 \\
\hline Baik & 12 & 24 \\
\hline Jumlah & $\mathbf{5 0}$ & $\mathbf{1 0 0}$ \\
\hline
\end{tabular}

Sumber: Data Lampiran 10

Berdasarkan tabel 2, menunjukkan bahwa dari 50 responden sebagian besar dengan self care activity cukup yaitu sebesar 36 responden $(72 \%)$.

\section{c. Tingkat Depresi}

Tabel 3. Distribusi Data Tingkat Depresi

Tingkat Depresi $\quad$ Frekuensi Persentase

\begin{tabular}{lcc} 
& $(\boldsymbol{f})$ & $(\boldsymbol{\%})$ \\
\hline Rendah & 17 & 34 \\
\hline Sedang & 30 & 60 \\
\hline Tinggi & 3 & 6 \\
\hline Jumlah & $\mathbf{5 0}$ & $\mathbf{1 0 0}$ \\
\hline
\end{tabular}

Sumber: Data Lampiran 10

Berdasarkan tabel 3, menunjukkan bahwa dari 50 responden, sebagian besar adalah responden dengan tigkat depresi sedang yaitu sebesar 30 responden (60\%).

\section{Analisis Bivariat}

Analisis hubungan self care activity dengan tingkat depresi pada pasien CHF di Poliklinik Jantung RSU Famili Husada menggunakan uji statistik Rank Sperman Test dengan $\alpha$ sebesar 0,05 , perhitungan menggunakan bantuan komputerisasi (perhitungan terlampir) dapat dilihat pada tabel 4 sebagai berikut:

Tabel 4. Distribusi Data Self Care Activity Dengan Tingkat Depresi

\begin{tabular}{|c|c|c|c|c|c|c|c|c|c|c|}
\hline \multirow{3}{*}{$\begin{array}{c}\text { Self Care } \\
\text { Activity }\end{array}$} & \multicolumn{6}{|c|}{ Tingkat Depresi } & \multirow{2}{*}{\multicolumn{2}{|c|}{ Total }} & \multirow{3}{*}{$\begin{array}{c}\mathbf{P} \\
\text { value }\end{array}$} & \multirow[t]{3}{*}{ nilai $\mathbf{r}$} \\
\hline & \multicolumn{2}{|c|}{ Rendah } & \multicolumn{2}{|c|}{ Sedang } & \multicolumn{2}{|c|}{ Tinggi } & & & & \\
\hline & $\mathbf{n}$ & $\%$ & $\mathbf{n}$ & $\%$ & $\mathbf{n}$ & $\%$ & $\mathbf{n}$ & $\%$ & & \\
\hline Kurang & 0 & 0 & 0 & 0 & 2 & 4 & 2 & 4 & 0.000 & -0.802 \\
\hline Cukup & 5 & 10 & 30 & 60 & 1 & 2 & 36 & 72 & & \\
\hline Baik & 12 & 24 & 0 & 0 & 0 & 0 & 12 & 24 & & \\
\hline Jumlah & 17 & 34 & 30 & 60 & 3 & 6 & 50 & 100 & & \\
\hline
\end{tabular}

\section{Sumber: Data Lampiran 10}

Tabel 4 diatas menunjukkan bahwa 2 responden (4\%) dengan self care activity yang kurang, terdapat 36 responden $(72 \%)$ dengan self care activity yang cukup dan 12 responden (24\%) dengan self care activity yang baik. Sedangkan 17 responden (34\%) memiliki tingkat depresi rendah, terdapat 30 responden $(60 \%)$ memiliki tingkat depresi sedang dan 3 responden $(6 \%)$ memiliki tingkat depresi tinggi.

Hasil uji statistik menggunakan rank spearman didapatkan nilai $\mathrm{p}=0,000(\mathrm{p}$ Value $<0,05)$, maka dapat disimpulkan ada hubungan Self Care Activity dengan tingkat depresi pada pasien CHF di Poliklinik Jantung RSU Famili Husada. Kuat hubungan antara self care activity dengan tingkat depresi pada pasien CHF dengan nilai $r=-$ 0.802 dengan arah hubungan negatif, bila semakin baik self care activity pasien maka tingkat depresi pasien CHF rendah.

\subsection{Pembahasan}

1. Karakteristik Responden Pasien CHF di Poliklinik Jantung RSU Famili Husada

Karakteristik responden seperti umur, berdasarkan hasil penelitian mayoritas pasien yang melakukan self care activity berada dalam rentang umur 56-65 tahun yaitu sebanyak 25 responden (50\%). Hal ini sejalan dengan (Laksmi, Suprapta and Surinten, 2020) berdasarkan usia responden menunjukkan sebagian besar responden berusia antara 51-60 tahun sebanyak 33 responden $(54,1 \%)$.

Bertambahnya usia sering dihubungkan dengan berbagai keterbatasan maupun kerusakan fungsi sensori. Kondisi sejalan 
dengan penelitian (Praptiwi, 2017) yaitu bahwa terjadi penurunan kemampuan belajar dan mendemonstrasikan aktivitas self care pada pasien congestive heart failure sebagai akibat penurunan fungsi sensori. Selain itu bertambahnya umur berpengaruh terhadap perkembangan disfungsi organ sebagai akibat upaya tubuh untuk mempertahankan homeostasis. Seiring bertambahnya umur akan berpengaruh terhadap perubahan struktur jantung, dimana terjadi penebalan dinding ventrikel kiri karena hipertensi atau peningkatan afterload (Rawla et al., 2018). Umur dapat meningkatkan prevalensi diastolic heart failure, hal ini disebabkan karena proses patofisiologi yang terjadi pada pasien usia lanjut, dimana terjadi rangsangan secara terus menerus pada sistem saraf simpatis akan meningkatkan kadar plasma norepinefrin (Lilly, 2013).

Karakteristik responden berdasarkan jenis kelamin didapatkan bahwa sebagian besar pasien dengan jenis kelamin laki-laki yaitu 30 responden $(60 \%)$. Hal ini sejalan dengan penelitian (Laksmi, Suprapta and Surinten, 2020) menunjukkan bahwa rata-rata adalah laki-laki yaitu sebanyak 40 responden $(65,6 \%)$. Secara medis sebenarnya laki-laki memiliki resistensi yang lebih tinggi terhadap gagal jantung dibandingkan perempuan. Jenis kelamin merupakan faktor risiko penyakit jantung, peranan hormon ekstrogen pada wanita bersifat memproteksi dari berbagai penyakit kardiovaskuler. Oleh karena itu, laki-laki rentan terhadap penyakit gagal jantung pada usia 50 tahun sedangkan perempuan pada usia 65 tahun atau setelah menopause (Praptiwi, 2017). Terdapat perbedaan faktor yang mempengaruhi kemampuan self care behaviour pada pria dan wanita. Pria lebih dipengaruhi oleh factor kontrol persepsi dan pengetahuan, sedangkan pada wanita faktor penting yang mempengaruhi adalah self care confidence dan status fungsional (Kaawoan, 2012).

Karakteristik responden menurut tingkat pendidikan didapatkan sebagian besar dengan pendidikan SMA yaitu 25 responden (50\%). Sama halnya menurut (Kaawoan, 2012) didapatkan dalam kategori pendidikan menengah dan atas yaitu tamat SMA sebanyak 34 responden (67\%). Tingkat pendidikan yang tinggi memiliki hubungan dengan kemampuan self care bahaviour dan kepatuhan terhadap pengobatan. Tingkat pendidikan sangat menentukan kemampuan pasien untuk memahami tentang kondisi kesehatannya. Kemampuan self care yang baik, akan mempengaruhi dalam pengenalan faktor dan efek jangka panjang terhadap kesehatannya. Oleh sebab itu, tingkat pendidikan berpengaruh terhadap kepatuhan pasien menjalani manajemen pengobatan (Kaawoan, 2012).

Karakteristik responden menurut pekerjaan sebagian besar Wiraswasta sebanyak 25 responden (50\%), sejalan dengan penelitian (Prihatiningsih \& Sudyasih, 2018) didapatkan sebanyak 39 responden yang masih bekerja $(52,7 \%)$. Bekerja sering dikaitkan dengan status sosial ekonomi seseorang. Bagi banyak pasien dewasa yang hidup dalam kondisi sosial ekonomi rendah serta tidak memiliki pendapatan tambahan selain gaji, akan mengalami kesulitan dalam beberapa aspek self care. Misalnya berhubungan dengan kepatuhan terhadap diet rendah garam, dan mengikuti program terapi sesuai anjuran dokter (Kaawoan, 2012).

\section{Self Care Activity pada Pasien CHF di Poliklinik Jantung RSU Famili Husada}

Berdasarkan tabel 2, Self care activity pasien CHF didapatkan cukup sebanyak 36 responden $(72 \%)$. Sejalan dengan penelitian (Kaawoan, 2012) didapatkan self care sedang sebanyak 30 responden (45\%). Self care activity digambarkan sebagai suatu proses dimana pasien berpartisipasi secara aktif dalam melakukan managemen self care secara mandiri atau dengan bimbingan keluarga maupun dibantu oleh petugas kesehatan. Perawatan diri meliputi; self care maintenance, self care management dan self care confidence (Kaawoan, 2012).

Menurut penelitian (Britz \& Dunn, 2010) yaitu studi mengenai kemampuan self care pasien heart failure yang dihubungkan dengan perubahan kualitas hidup, menunjukkan bahwa hanya self care confidence dan persepsi yang baik terhadap kesehatan yang mempunyai hubungan signifikan dengan peningkatan kualitas hidup. Dalam penelitian (Praptiwi, 2017) menemukan bahwa peran perawat klinik heart failure terbukti dapat meningkatkan 
kemampuan hidup serta mempertahankan perilaku self care yang baik, hal ini ternyata mampu menurunkan angka kejadian penyakit dan re-hospitalisasi. Menurut (Kaawoan, 2012) menyatakan bahwa program self care management dapat menurunkan kejadian hospitalisasi dan re-hospitalisasi pada pasien heart failure, serta dapat meningkatkan kualitas hidup.

\section{Tingkat Depresi pada Pasien CHF di Poliklinik Jantung RSU Famili Husada}

Berdasarkan tabel 3, tingkat depresi pasien CHF sedang sebanyak 30 responden (60\%). Sejalan dengan penelitian (Kaawoan, 2012) didapatkan tingkat depresi sedang sebanyak 49 responden (62\%). Depresi merupakan kondisi yang umum terjadi pada pasien CHF, secara signifikan mempengaruhi kualitas hidup pasien, hasil akhir yang diharapkan paien mampu memanfaatkan fasilitas pelayanan kesehatan (Praptiwi, 2017). Depresi menyebabkan hambatan fungsi fisik pasien, meningkatkan derajat keparahan gejala penyakit dan secara umum menyebabkan perubahan kualitas hidup. Pasien CHF dengan kondisi depresi berisiko tinggi untuk mengalami re-hospitalisasi dan apabila terjadi perburukan kondisi akan mengalami kematian.

Studi lain menyebutkan bahwa mekanisme perilaku berhubungan dengan kejadian depresi yang meliputi pola hidup yang tidak sehat seperti merokok, obesitas, tidak mematuhi diet, konsumsi alkohol dan ketidakpatuhan lainnya, yang secara langsung berdampak pada angka kematian (McGowan, 2014).

\section{Hubungan Self Care Activity dengan Tingkat Depresi pada Pasien CHF di Poliklinik Jantung RSU Famili Husada}

Hasil uji statistik rank Spearman Test pada tingkat kemaknaan $\alpha=0,05$ dengan nilai yang diperoleh sebesar 0,000 ; dengan demikian nilai $<\alpha$ maka Ho ditolak dan $\mathrm{Ha}$ diterima. Hal ini menunjukkan ada hubungan self care activity dengan tingkat depresi pada pasien CHF di Poliklinik Jantung RSU Famili Husada.

Menurut (McGowan, 2014) menyebutkan bahwa mekanisme perilaku berhubungan dengan kejadian depresi yang meliputi pola hidup yang tidak sehat seperti merokok, obesitas, tidak mematuhi diet, konsumsi alkohol dan ketidakpatuhan lainnya, yang secara langsung berdampak pada angka re-hospitalisasi. Menurut (McGowan, 2014) kejadian depresi mempengaruhi kualitas hidup pasien, tetapi juga secara signifikan meningkatkan risiko kematian bila tidak menjalankan managemen self care. Depresi terbukti menjadi faktor yang kuat menurunkan status kesehatan. Depresi menyebabkan hambatan fungsi fisik pasien, meningkatkan derajat keparahan gejala penyakit dan secara umum menyebabkan perubahan kualitas hidup.

Sebagian pasien menyatakan belum melaksanakan self care (perawatan diri) dengan baik seperti mematuhi pengobatan yang diberikan, diet rendah garam, berolahraga, pembatasan cairan, monitor berat badan. Sehingga menyebabkan gejala yang dirasakan semakin berat dan pasien menjalani hospitalisasi. Maka dari itu, penting meningkatkan kemampuan self care pada pasien CHF (Britz and Dunn, 2010).

Menurut (Prihatiningsih and Sudyasih, 2018) merekomendasikan bahwa aktivitas fisik dapat meningkatkan kualitas hidup. Aktivitas fisik dapat mengurangi rasa cemas, kesal, dan marah, karena oksigen yang masuk saat aktivitas fisik ke otak akan memberikan rasa nyaman.

Menurut (Britz and Dunn, 2010) studi deskripsi mengenai kemampuan self care pasien heart failure, menunjukkan bahwa hanya self care confidence dan persepsi yang baik terhadap kesehatan yang mempunyai hubungan signifikan dengan peningkatan kualitas hidup. Dalam penelitian (Prihatiningsih and Sudyasih, 2018) menemukan bahwa peran perawat klinik heart failure dapat meningkatkan kemampuan pasien serta mempertahankan perilaku self care yang baik, hal ini mampu menurunkan angka kejadian penyakit dan rehospitalisasi serta jumlah hari rawat. Penelitian (Kaawoan, 2012) menyatakan bahwa self care management dapat menurunkan kejadian hospitalisasi dan rehospitalisasi bagi pasien heart failure, juga dapat meningkatkan kualitas hidup pasien CHF. 


\section{KESIMPULAN}

Berdasarkan hasil penelitian, self care activity berkolerasi secara signifikan dengan dengan tingkat depresi pada pasien CHF di Poliklinik Jantung RSU Famili Husada dengan korelasi positif yang cukup kuat dengan nilai $\mathrm{p}=0,000 \alpha=0,05$ dan $\mathrm{r}=$ 0.802 , semakin baik self care activity maka tingkat depresi pada pasien CHF semakin rendah.

\section{REFERENCES}

Benjamin, E. J. et al. (2017). Heart Disease and Stroke Statistics 2017. Update: A Report from the American Heart Association Circulation. https://doi.org/10.1161/CIR.0000000000 000485.

Britz, J. A. and Dunn, K. S. (2010). Self-care and quality of life among patients with heart failure. Journal of the American Academy of Nurse Practitioners. 22, 480-487.

Dinas Kesehatan Provinsi Bali. (2018). Profil Kesehatan Dinas Kesehatan Provinsi Bali 2017. Denpasar: Dinas Kesehatan Provinsi Bali.

Kaawoan, A. Y. A. (2012) 'Hubungan Self Care dan Depresi dengan Kualitas Hidup Pasien Heart Failure di RSUP DR RD Kandou Manado', Universitas Indonesia, pp. 1-87. Available at: http://lib.ui.ac.id/file?file=digital/203046 05-T30728 - Hubungan Self.pdf.

Laksmi, I. A. A., Suprapta, M. A. and Surinten, N. W. (2020). Hubungan Self Care Dengan Kualitas Hidup pasien gagal jantung di RSUD Mangusada: Jurnal Ilmiah Ilmu Kesehatan.

Lilly, L. S. (2013). Pathophysiology of heart disease: A collaborative project of medical students and faculty: Fifth edition, Pathophysiology of Heart Disease: A Collaborative Project of Medical Students and Faculty: Fifth Edition.

McGowan, J. (2014). Psychology, mental health and distress Psychosis. British Journal of Cardiac Nursing, 6 (1), 1925.

Praptiwi, W. S. (2017). Gambaran Tingkat Depresi Pada Penderita Congestive Heart Failure (CHF) Di Poliklinik Jantung Rumah Sakit Umum Pusat Dokter Soeradji Tirtonegoro Klaten. Universitas Muhammadiyah Surakarta.

Prihatiningsih, D. and Sudyasih, T. (2018). Perawatan Diri Pada Pasien Gagal Jantung: Jurnal Pendidikan Keperawatan Indonesia.

Rawla, P. et al. (2018). Hubungan Antara Self Management Dengan Kualitas Hidup Pasien Congestive Heart Failure (CHF) DI RSUD dr. Moewardi Surakarta.

Riskesdas. (2013). Hasil Utama Riset Kesehatan Dasar (RISKESDAS). Jakarta: Kementrian Kesehatan RI.

Riskesdas. (2018). Hasil Utama Riset Kesehata Dasar (RISKESDAS). Jakarta: Kementrian Kesehatan RI.

Smeltzer, S. \& and Bare, B. (2017). Buku Ajar Keperawatan Medikal Bedah Edisi 8. Jakarta: EGC.

Tatukude, C., Rampengan, S. H. and Panda, A. L. (2016). Hubungan Tingkat Depresi Dan Kualitas Hidup Pada Pasien Gagal Jantung Kronik Di Poliklinik Jantung Rsup Prof. Dr. R. D. Kandou Manado. e-CliniC, 4(1). 